店 列

二期的手術により救命しえた腸管ベーチェットによる 穿孔性腹膜炎の 1 例

帝京大学医学部第 1 外科（主任：四方凉一教授）

公平不二雄 山川達 郎

\title{
A CASE OF GENERALIZED PERITONITIS DUE TO INTESTINAL BEHCET PERFORMED TWO STAGE OPERATION
}

Fujio KOHDAIRA and Tatuo YAMAKAWA

The First Department of Surgery, Teikyo University, School of Medicine, Tokyo

(Director : Prof. Junichi Shikata)

腸管ベーチェットによる穿孔性汎発性腹膜炎に対し，腸管の腹腒外昿置術を施行し，2 期的に治憥せしめえた症例を経験し，その経過の概要を報告するとともに，本症の治療に 閔し，1考察を加えた。

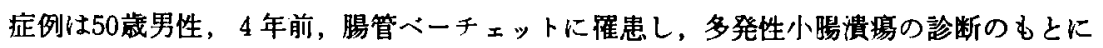
結腸右兴切除術をうけている. 今回は腹痛をま訴として入院し，吻合部に再発した潰湯の

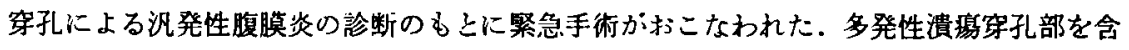
めて腸管の腹整外胘置術を施行し，腹膜炎症状の消腿と腸管ベーチェットの寞解を待っ て，昡固腸管切除ならびに腸管吻合術を行った。術後，㓣倿哆開をみたが 2 期手術後80日 目に無蚄退院した。

\section{はじめに}

晹管ベーチェットは，增悪・寞解を反復しつつ，慢性 に経過する全身性炎症性疾患の一部であり，潰瘍を主症 状とし，難治性であり穿孔をきたしやすく，穿孔は重篤 な状態を若起するものである．さらら潰碣穿孔時の腸管 切除ならびに再建術は，䋖合不全の発生率が高く"，そ の子後を不良とすることから，その治療法に関しては議 㕟の多いところである.

我々は, ベーチェット病起因の回腸・横行結腸吻台部

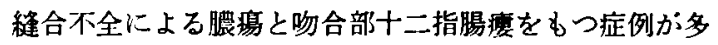
発性回腸穿孔により沉発性腹膜炎をきたしたので，祭急 手術により穿孔部を含めた腸管の腹照外眙置術を施行 し，二期的に脏固腸管を含めて回腸ならびに結腸の部分 切除を施行して治窟せしめた程䮖を報悲する。

\section{应例}

患者 : 50歳，男性.

家族歴ならびに既応歴：特記すべきことなし．
現病歴：昭和51年 2 月頃より，口㔖内フフタ，外陰部 演瘍，皮疹，回盲部痛が周期的に出現するよ5Kなっ た. 昭和51年 5 月，症状が次第に增悪する傾向があるた め, 某大学病院で精查を受け，回腸・上行結腸に多発任 潰場が発生していることが判明し，腸管べーチェットの 診断のもとに結腸右半切除術が施行された。.その後の虽 過は良好であったが，再び昭和55年 1 月頃より回盲部痛 が出現し，次第に增悪傾向を示したため，昭和55年 3 月，当院第 2 内科を受診，腸管べーチェットの診断を受 けた，注腸造影で，回腸・横行結腸吻台部に溃梅が認め られ，またここれと十二指腸との間に磨孔がみられた。 その後，内科的治療を続けたが，昭和55年 8 月 6 日，上 腹部痛，悪化，呕吐が出現して第 2 内科再入院し，9月 6 日外科転科となった。

転科時所見：体格中等度. 柴着良好. 体温 $40^{\circ} \mathrm{C}$. 脈拍 $100 /$ 分整，緊張良好. 眼眕結膜貧血様. 体表リンハ節は 特に触知せず，口腔内にフフタを認めるも，皮疹や外部 
陰蛽疸は認められなかった。

股部所見：腹部軽度膨隆. 腹部全体に压痡, 抵抗なら びに筋性防御を認さ。直腸指診にてもダグラス窝全体に 軽い压痛を認めた。

俣亘所見：赤血球数 $417 \times 10^{4}$ ，白血球数 12,400 ，血色 素量 $13.8 \mathrm{~g} / \mathrm{dl}$ ，へマトクリット值 $40 \%$ ，血小板数 $19.2 \times$ $10^{4}$ ，粉蛋白量 $4.3 \mathrm{~g} / \mathrm{dl}$ ，尿素空素 21 , 総ビリルビン值 1.7, GOT 34, GPT 39, LDH 244, AL-P 6.8, rGTP 44, Ch-E 0.15, 続ュレステロール值55, プロトロンビ ン時間14.2秒，部分トロンボプシスチン時間 $62 \%$ ， フ ヘブリノーゲン530，FDP 10，CRP 6+，血沈值60分 $87 \mathrm{~mm} 120$ 分 $138 \mathrm{~mm}$, ワッセルマン 反応 $(-)$, TPHA $(-)$.

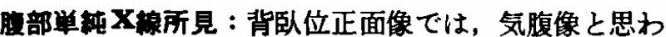
れるガス像が認められ，腰筋線陰影は両側とも消失して いた.

昭和55年 8 月11日に，内科で行った注腸造影所見（写 真1）では，回腸・横行結腸吻合部に一致する深い潰湯 性病変を認めたまた，この写真には撮っていないか， ここと十二指腸下行脚との間に㾯孔の形成がみられた。

以上の所見より，潰瘍性病変の穿孔に上る汎発性腹膜 炎との術前診断のもとに 9 月 6 日開腹手術を行った.

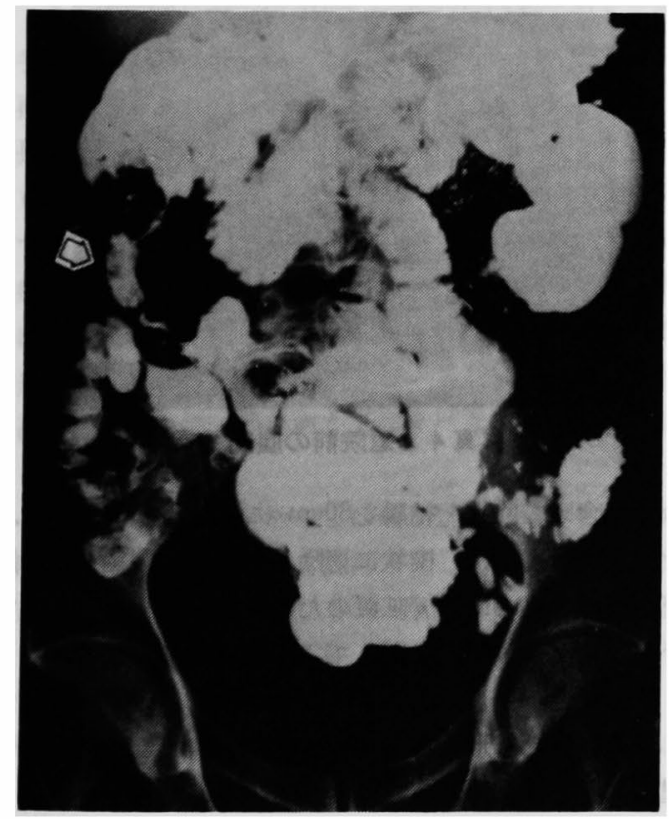

写真1 注腸造野（矢印は，回腸・横行結腸吻合 部の溃赛を示す。）
初回手術所見（図 1）：前回手術による腹壁疫痕部之 小腸とが密に密着し，さらに十二指腸下行脚から右肝下 部にかけて約 $100 \mathrm{ml}$ の黄白色の瑻计が認められ, 吻合 部䋖合不全による腹腔内膿場と考えられた。 また，トラ イッ靱帯より $50-70 \mathrm{~cm}$ 肛門側の空腸には 2 個の，そし て回腸末端部には多数のそれぞれ潰楊によると思われる 腸管壁の菲薄化がみられた。ささらにトライッ靱帯より $100 \mathrm{~cm}$ 肛門側飞 1 個の, そして回腸末端部 $20 \mathrm{~cm}$ 以内 に 2 個の穿孔が認められた，腸壁の炎症性変化による発 赤は特に下部回腸に強かったが，これらの謴富が周囲藏 器に被覆されていることはなかった。吻合部は，十二指 腸と強固に瘾着していた，術中，吻合部が開いたため， ここより吻合部と十二指腸との間に瘦孔，すなわち回腸 ・横行結腸・十二指腸湄があることが認められた.

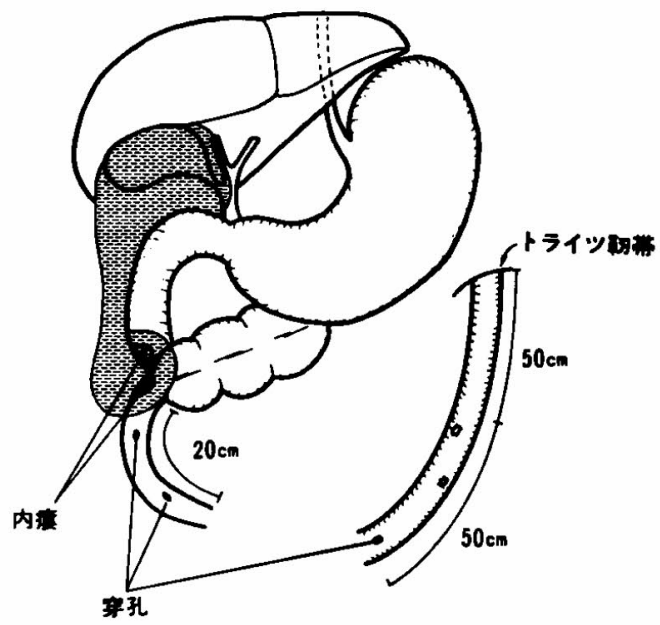

园1初回手術所見

初回手郝々式：トライッ靬带より $100 \mathrm{~cm}$ の穿孔部は 制状に切除し程合・閉鎖するのにとどめ，十二指腸の下 行脚ならびに水平脚を十分に授動し、これと吻合部およ び炎症所見の強い吻合部より口側の回腸 $80 \mathrm{~cm}$ とを穿孔 部を含めて一塊として腹肤外に眙置した。

各穿孔部より小腸内に，ならびに吻合部の開いた盿孔 より十二指腸内にフォリーカテーテルを㨀入して腸液を 体外に誘導し，消化液による皮庙の炎症を予防した（写 I 2 ).

術後経過 : 術後は, 禁食とし中心静脈栄養により栄養 状態を管理した。 また，次の手術時期を決定するため， 腹膜炎症状の消腿，さらにべーチェット病の主症状であ 


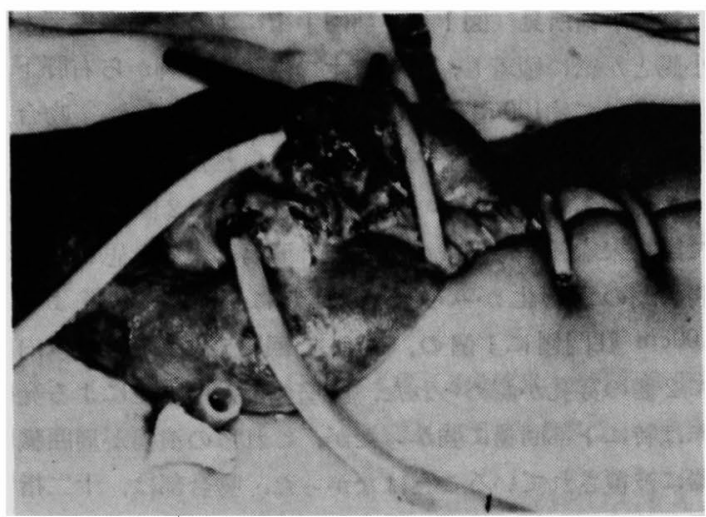

写克 2 初回手術主传の脑部厉見

るロ晄内フフタ，外陰部濆湯，皮疹を観察しながら， CRP，血沈値などの 検㚗所見を一定間隔でチェックし た.

発赤が著明であった暖置腸管は，急性期を脱するとと むに正常化したので（写索3），昭和56年 2 月 9 日，二 期手術を行った.

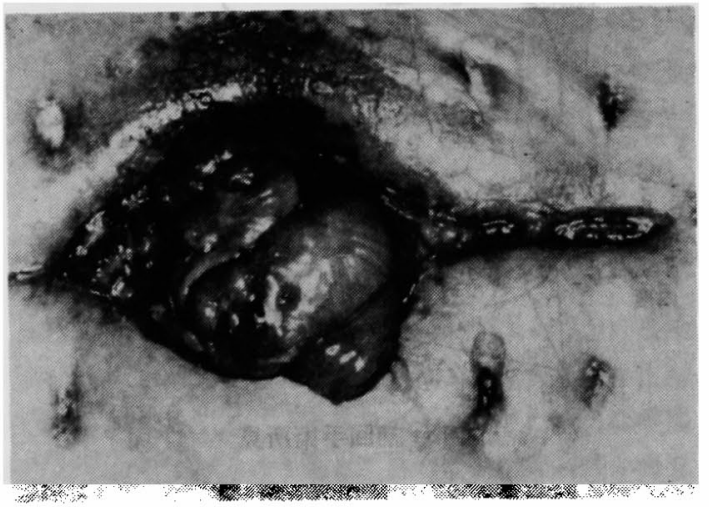

写克 32 期手術前の湖部所見

二期手術前検查所見 : 赤血 球数 $319 \times 10^{4}$, 白血球数 5,100 , 血色素量 $11.7 \mathrm{~g} / \mathrm{dl}$, ヘマトクリット値 $32 \%$, 血小 板数 $15.6 \times 10^{4}$, 総蛋白量 $7.0 \mathrm{~g} / \mathrm{dl}$, 尿素窒素 15 , 総ビリ ルビン値1.5, GOT 14, GPT 28, CRP士, 血沈値60分 $20 \mathrm{~mm}, 120$ 分 $65 \mathrm{~mm}$.

2 期手術所見ならびに術式：腹腔内膿埸は認められ ず，前回手術時にみられた小腸の炎症所見や潰瘍による と思われた腸管壁の菲薄化は見られなかったし，小腸同 志の䓌着はきわめてわずかであった，腹壁と小渴ならび に小腸間膜との瘾着を制離したのち，図 2 のごとく，物

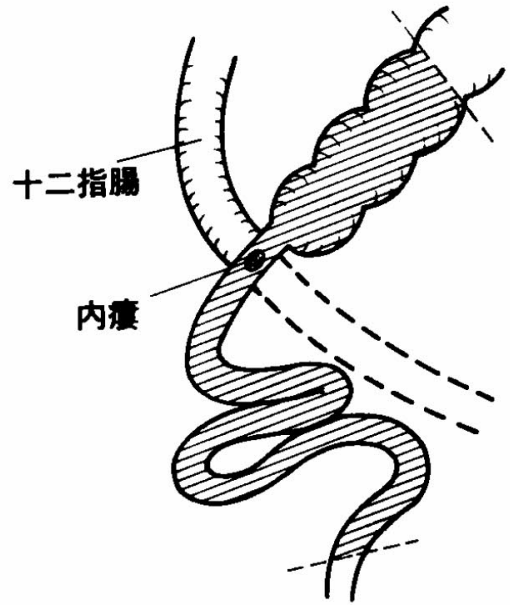

因22 期手術所見

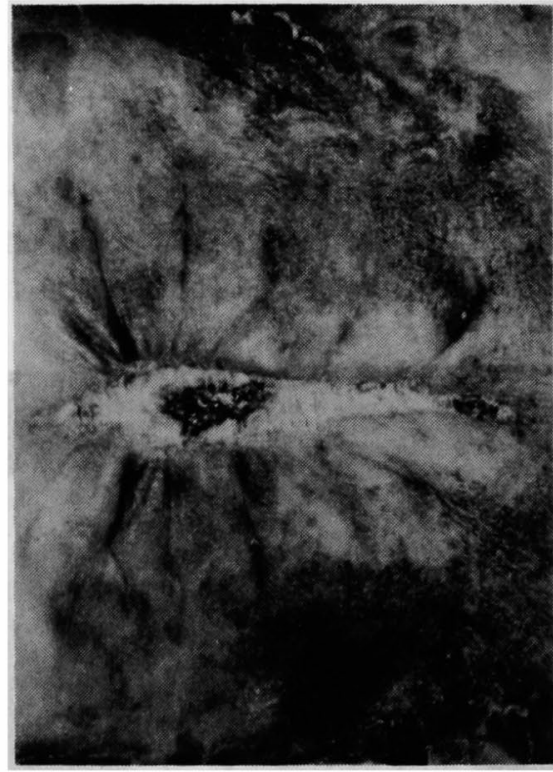

写克 4 退院前の㧤部所見

合部を含めて回腸・結腸を $80 \mathrm{~cm}$ にわたって妢除した 十二指腸瘄孔部は，揳状に切除して程合：閉鎖した。腹 壁閉鎖に当っては腸管昿置のために腹壁欠損をきたして いたので，減張切開を加えてよらゃく閌腹しえた。

術後辁远：術後は, 腹壁の緊張が強く，創哆開をきた したか，肉芽を形成して治空し，術後80日目に無事軽快 退院した（写而4）.

考察

本邦において報告された晹管ベーチェットは,ベーチ 
×ット病全体からすると1\%弱であるが, 何らかの形で 消化器症状をもった患者は，40\%近くに認められると報 告されている2).

腸管べーチェットにおける湞疸の特長は，本例の X線 所見で認められた如く，円形謴煬で下䏱れがあり，ま た，小さい割に深く，また，淇芴底は，膠原線維の反応 か弱く穿孔をおこしやすいとされている゙．組織学的に は，軥管ベーチェットに特有の，固有筋署が完全に断裂 した深い潰場が認められ，裂孔が高頻度に認められるこ とも穿孔をおこしやすい一因とされている゙。

腸管に責鹃をみつけたら常に手術の対象とすべきであ るとする中野の意見 ${ }^{2)}$ に対して，保存的療法でるかなり

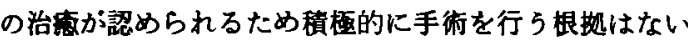
のではないかといら意見むあるが，馬場らの全国集計 における㗨急手術例は53.8\%あり"，その5ち，50\%は 穿孔性腹膜资侏発例であった事実を考えあわせても，中 はり，渴管ベーチェットの特長をもった潰楊に対して

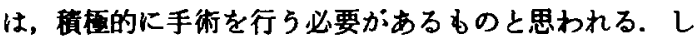
かしながら，增悪期における手術成績がよくないことを 考之”，さらに主症状の消腿および血沈值，CRPなど をこまかくチェックし，本应特有の増悪・宽解の周期を 知り，寛解期に手術を行らことも手術を成功させるため には重要なことと考えられる。

さらに児玉らは，本邦で報告された待期手術を含めた 手術例54例の集計を行った：その5ち10例（約23\%）か～

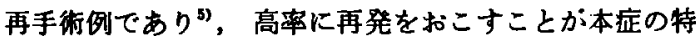
長としている. その再発は，極めて早期に起こる可能性 もあり，その原因は，端合系の刺激が漬膓の再発に関与 する゙といら報告もあるか，手術時期が, ベーチェット 病の增覀期に行なわれることが多いために再発するので はないかとも考えられる。また一般に，腸管吻合を腹膜

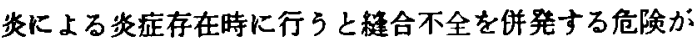
高くなるため段階的手術を考虑すべきであるとする意見 むある12.

前谷らむ，腹壁開放および罹患腸管の外瘦化すなわち 腸管空着および䶺着術を施行することにより，より良い 結果を得たと報告している”。また，やはり同様に腹壁 を開放すると，腹腔内が好気的になることが良い結果を るたらすとしている゙。

本症例は，腸管ペーチェットにより広範囲の腸管がお。 かされていたこと，穿孔性汎発性腹膜炎により炎症性変 化か強かったこと，さらに空腸・横行結腸・十二指腸な
らびにその附近の腹跴内港瘍があったことなどから，穿 孔部を含めて罹患腸管を腹腔外に昿置し，腹膜炎症状の 消腿をむち、ベーチェット病の増悪期を乗り切って寛解 期に 2 期的手術を行い，重䉆な合併症もなく治空したす のである．よって本症例のごとく，広籍囲に腸管が昌さ 九资症々状の強い時は，姑息的な外瘖化手術を行い，腹 腔内および腸管の安静をはかり，炎症々状の消腿をまち 再手術したことが救命しえた大きな因子であると思われ た.

\section{結 再}

腸管ベーチェットが一般に手術成精が不良であるとい らことは，溃場の悪化するぺーチェット病の増悪期に手 術が行なわれることが一因をなしていると考えられるの で，段階的手術として穿孔存在時の手術法としては腹腔 外腸管昿䁂術をる考感すべきであると考えられる。

稿を䅂るにあたり、こ指導とご校閲を睗わった四方淳 一教授に深く深謝いたします。なお，御教示いたたい た、本学第 2 内科の各先生に深誎らたします。

（本論文の要旨は第 701回外科集談会でロ演した。） 文献

1) 山川達郎, 四方淳一：下部結腸吻合部䋖合不全 一區床および害呀的研究, 日消外誌, $7: 46-$ $51,1974$.

2）中野新一：腸管ペーチェットの外科的意義, 福 島医学誌, $27: 87$ 二117, 1977.

3) 高田好彦：Intestinal Beh et の臨床的および 病理組樴学的研究一 7 症例の分析 : 特に潰煬の 発生機序に開する考察六, 北里医学, $8: 363$ 一 $379,1978$.

4) 渡辺 勇, 桑原紀之, 福田芳郎 : 腸管型 Behçet 病の病理組械学的研究, 胃と腸, 14：903913, 1979.

5) 馬場正三 : 腸型 Beh et 病の臨床, 胃と腸, 14: $885-891,1979$.

6) 児玉 宏, 大垣和久, 稻本 俊他: 術後吻台部 に再発を繰返した Intestinal Behçet, 最新医 学, $33: 1411-1419,1978$.

7) 前谷俊三：消化管，特に小腸の栈合不全の病熊 と対策, 消化器外科, $3: 289-298,1980$.

8) Steinberg, D.: On leaving the peritoneal cavity open in in acute generalized suppurative peritonitis, Am. J. Surg., 137: 216-220, 1979. 